\section{Imaginary orderliness}

SIR - The situation at the Natural History Museum (NHM) is as serious as any that has faced Britain's 'national' museums in recent times. Yet the bulk of Sir Walter Bodmer's Commentary (Nature 345, 569; 1990) appears to ignore reality in a push for the status quo.

Professor John Evans, immediate past president of the Geologists Association, through his comments (reported by Henry Gee in Nature 345,$99 ; 1990$ ) on the corporate management proposals of the museum's director, Neil Chalmers, is working to advantage only the agenda of those intent on pursuing the narrow rational economic agenda. Statements such as "[the plan] has . . . been cobbled together in American-style business jargon presumably courtesy of Disneyland where many of the museum's administration went to learn such jargon" can surely be described only as ignorant nonsense.

The NHM is studying Disneyland so as to give visitors better service: that is good. Disneyland is expert at excellent customer services. That contributes more to the continuation of the NHM's outstanding work than abuse from single-interest groups who wish to brand everything about management as a fascist plot.

Evans' successor, Professor Beverly Halstead, long-time critic of changes at the museum in exhibitions which are based on very good research and sound judgement, has also done little to help the museum by his recent comments.

Detailed analysis of the corporate plan and of whether it is an appropriate response to the future is well worthwhile. But that exercise should surely use the same caution and logic as is applied by scientists to their own research.

The problem is the British government and its continued refusal to recognize the enormous importance of museums in all areas of science and education. And its failure to recognize their importance in economic terms is shown by recently published studies (for example, The Economic Importance of the Arts by John Myerscough, Policy Studies Institute, July 1988).

To help the museum and its staff and (most of all the public), the last thing one should do is to campaign on single-issue agendas such as taxonomy and the 'undesirability' of changing direction. I am astonished at the narrowness of view of many of the scientific groups expressing concern. Reading some of the draft letters that are circulating, one would imagine that the only problem resulting from reductions in the museum's funding was the loss of knowledge of sponges or crustaceans. Of course this is important, but it is the existence of the museum which is at risk. Only if that is secured will it be possible to discuss its shape and future programmes.

What would the Geologists Association do to reverse the trend at the museum towards salaries exceeding the total money granted by government? Presumably 132 years have taught them something. Try joining together with others concerned about the future of museums to put pressure on the government. It is a political issue after all.

DES GRIFFIN

(Chairman, Council of Australian Museum Directors)

Australian Museum,

6-8 College Street,

Sydney 2000, NSW,

Australia

SIR-Sir Walter Bodmer, writing as chairman of the trustees of the Natural History Museum (NHM), has defended the recent corporate plan of this museum ${ }^{1}$. He argues that, given a shortfall in funds, the scientific programme was the only area left in which cuts could be made. He points out that many scientific posts have been lost in the museum over the past five to seven years by random natural wastage and claims that, because of this randomness, "the director and his senior staff [have had to] assess research priorities" so that any further cuts would occur in a more orderly way.

Such orderliness is imaginary, however, for the imposed cuts do not fit any scientific plan. They were decided by heads of departments in obedience to the command: "Your department will lose $x$ posts and you will decide which ones".

This command produced many anomalies where the redundancies run counter to the ostensible aims of the plan. To give one example out of many ${ }^{2}$, the museum, under the plan, is supposed to be more environmentally aware than in the past and we accept this aim. Nevertheless, research is to stop in diatoms, which are first-class environmental indicators of particular value in reconstructing the course of global warming. Many of these anomalies have been mentioned in parliament by $\mathrm{Mr}$ Tam Dalyell $\mathrm{MP}^{3}$.

The brutality of the plan, the highhandedness with which it was announced, and other insults dealt to us by management, have demoralized the staff and produced many requests for voluntary retirement additional to those which the management originally called for. It is true that these requests are randomly distributed scientifically, but so are the cuts proposed by the plan. Allowing some requested retirements would provide several free posts and enough money to restore some of the axed curatorial and research positions. We therefore urge management to reassess the cuts with all this in mind.

After all, Sir Walter Bodmer would never claim that the museum is stronger without several axed scientists who dearly wish to stay, including a certain worldfamous archaeozoologist and an internationally known palaeobotanist.

\section{P. E. J. WHEATCROFT} (Branch Chair)

R. P. S. JEFFERIES

(Secretary, Science Defence Committee) Institution of Professionals, Managers and Scientists,

Natural History Museum,

Cromwell Road, London SW7 5BD, UK

1. Bodmer, W. Nature 345, 569-570 (1990).

2. Science Defence Committee Corporately Planned Damage to Science (IPMS (Natural History Museum Branch) 1990)

. Dalyell, T. Hansard 174 (118, for 11 June 1990), pp.18, 77, 102 .

\section{Journal titles}

SIR-I commend Dr Judah Rosner's comments on the unseemly dogmatism of the AST (assertive sentence title). Perhaps he is right in suggesting that some scientists embrace this style in order to impress granting agencies. But there is one other factor. In 1981, Martin Glennie and I submitted to Nature an article with the fuddy-duddy title "The use of univalent antibodies to kill tumour cells". It was published as the resounding "Univalent antibodies kill tumour cells in vitro and in vivo". Had we in the intervening months become more thrusting and positive? Not in the least. The title was altered in the editorial office of Nature.

G. T. Stevenson

University of Southampton

Lymphoma Research Unit,

Southampton General Hospital,

Southampton SO9 4XY, UK

\section{Eminent engineers}

SIR-Not only was President Herbert Hoover an engineer (Nature 345, 106; 1990 ), but he had strongly held views on the value of education. He wrote in 1941 that "British universities [had] refused to incorporate engineering into their curricula until much later than the Americans. In the meantime, the American engineers - especially the mining engineers - flooded the British Empire" (Foreword to T. T. Read's The Development of Mineral Industry Education in the United States, New York, 1941).

We would certainly be helped if Hoover's positive attitude to training engineers prevailed in British politics today.

Department of Geology,

HUGH TORRENS

The University,

Keele, Staffs ST5 5BG, UK 